\title{
ADSORPTION OF HEAVY METALS (LEAD ION) FROM INDUSTRIAL WASTE WATER USING ACIDIFIED BENTONITE CLAY
}

\author{
Ogbe Idoko \\ Department of Science Laboratory Technology \\ University of Jos, Jos, Plateau State, Nigeria \\ John Stephen Gushit \\ Department of Science Laboratory Technology \\ University of Jos, Jos, Plateau State, Nigeria
}

\author{
Michael Olasunkanmi Ajana \\ Department of Science Laboratory Technology \\ University of Jos, Jos, Plateau State, Nigeria \\ Alexander Jock \\ Department of Science Laboratory Technology \\ University of Jos, Jos, Plateau State, Nigeria
}

\begin{abstract}
The adsorption potential of acidified bentonite clay obtained from Adamawa state; a location in North Eastern Nigeria was investigated through batch experiments conducted to remove $\mathrm{Pb}^{2+}$ from an aqueous solution. A constant weight of $0.5 \mathrm{~g}$ of acidified bentonite clay was used throughout the experiment. $\mathbf{P b}^{2+}$ adsorption was found to be dependent on initial concentration, contact time, temperature and pH. An initial metal ion concentration of $50 \mathrm{ppm}$ and 10ppm gave maximum uptake $(99 \%)$ and minimum uptake $(87 \%)$ respectively. Temperatures of $70 \mathrm{o}$ $\mathrm{C}$ and 50 o $\mathrm{C}$ altered the adsorption; giving $(\mathbf{9 9 . 7 5 \% )}$ and $(96.2 \%)$ as maximum and minimum uptakes respectively. A 99.93\% adsorption was recorded as maximum at contact time of 10.0 min while $95.79 \%$ was the minimum at 40.0 min. At pH level of 6.0, adsorption was maximum $(\mathbf{9 8 . 8 \%})$ and minimum $(89.8 \%)$ when $\mathrm{pH}$ was reduced to 4.0 . Experimental isotherm data were analyzed using the Langmuir, and Freundlich equations. The kinetic processes of $\mathrm{Pb}^{2+}$ adsorption on the bentonite clay were described by applying pseudo-first order and pseudo-second order rate equations. The kinetic data for the adsorption process obeyed pseudo-second order rate equations. $\mathbf{R}^{2}$ was used to enhance the justification analysis for each used model (1st order: $R^{2}=0.423$, 2 nd order: $R^{2}=1$, intra particle diffusion model: $\left.R^{2}=0.997\right)$. The acidified bentonite clay investigated in this study exhibited a high potential for the removal of $\mathbf{P b}^{2+}$ from aqueous solution.
\end{abstract}

Keywords - Bentonite Clay, Beneficiation, Heavy metals, waste water.

\section{INTRODUCTION}

Environmental pollution is becoming a great concern and better technologies for wastewater treatment are being tested. The availability of cheaper and more efficient adsorbents have led to more research in the area of effective and economic adsorption process. One of these areas of research according to Ming Qin J et al. (2009) focuses on cation exchange resins, such as clay, to abate wastes from contaminated water. Generally, Industrial discharge is the major cause of contamination to the environment (Kadirvelu et al. 2003). Wastewater consist mainly of oxygen- demanding materials, grease, oil, scum, pathogenic bacteria, viruses, pesticides, refractory organic compounds and heavy metals (Grassi et al. 2012).

\section{A. Bentonite Clay}

Bentonite is an aluminum phyllosilicate clay consisting primarily of montmorillonite. The name was given by Wilbur C. Knight in 1898 after the Cretaceous Benton Shale close to Rock River, Wyoming (Hosterman and Patterson, 1992). The various types of bentonites were each named after their respective dominant element; potassium $(\mathrm{K})$, sodium $(\mathrm{Na})$, calcium $(\mathrm{Ca})$, and aluminum $(\mathrm{Al})$. Bentonite is widely used in manufacturing of paints, greases, oil-based drilling mud, cosmetics, pharmaceuticals, detergents, paper and in wastewater treatment. The demand for bentonite depends majorly on the growth of end-user industries that utilize it to produce various products. Hence, future demand for bentonite is dependent on growth of the national economy, especially the manufacturing sector (Gutierrez and Fuents, 1996).

\section{B. Heavy Metals in Industrial Wastewater}

Toxic metals ions find their way into water bodies through wastewater discharge from metal plating industries and factories of batteries, mining, and pigments. They are present in the environment in different forms; the most common forms are chloride, oxides and nitrate (Kadirveluetal.2003). Other common sources include: wastewaters of electroplating, leather tanning, cement, petrochemical, refinery and paint industries. Heavy metals are removed by precipitation, membrane separations, solvent extraction etc. These techniques are challenged by the removal of lower concentrations of metals from solution. Alternatively, adsorption is a simple, selective and economic process for removing heavy metal ions from wastewater (Kadirveluetal.2003). This may be due to the simplicity, effectiveness, low cost and abundance of absorbents like bentonite clay. Wastewater treatment with bentonite is based on its ion exchange and adsorption mechanisms, with relatively high cation exchange capacity (CEC) and specific surface area. Bentonite holds pollutants and prevents downward movement of wastewater. It is therefore important to know the retention capacity of bentonite alongside the factors that govern cation retention (Ming Qin J et al. 2009). Heavy metals are 


\section{International Journal of Engineering Applied Sciences and Technology, 2019 Vol. 4, Issue 4, ISSN 2455-2143, Pages 394-401 Published Online August 2019 in IJEAST (http://www.ijeast.com)}

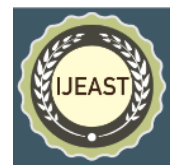

metals or metalloid having high density, and known for their toxicity. They include; lead, chromium, cadmium, nickel, mercury etc. these Heavy metals are natural constituent of the environment. World Health Organization (WHO) specifies the maximum allowable concentration of heavy metals that should be present in any eatable and drinkable substances as $0.005 \mathrm{~g} / \mathrm{L}$ (WHO, 2011; Bosch et al., 2016). Intake of heavy metal like arsenic can cause cancer of the skin and pulmonary diseases when taken above the WHO recommendations. Toxicity depends on several factors including the dose, route of exposure, and chemical species, as well as the age, gender, genetics, and nutritional status of exposed individuals. As a result of their high level of toxicity, arsenic, cadmium, chromium, lead, and mercury rank among the priority metals that are of public health significance (Lenntech, 2012; Asli Baysal et al. 2013). The known fatal effects of heavy metal toxicity in drinking water include damages or reduced mental and central nervous function and lower energy level .They also cause irregularity in blood composition, acute and chronic effect on vital organs such as kidneys and liver. (Sher Ali Khan et al., 2011).

\section{MATERIALS AND METHODS}

\section{A. Materials}

The materials used for this research work include: Bentonite clay, wastewater (Simulated), Portable water, Deionized water.

\section{B. Equipment's and Apparatus}

The equipment's used for this research work includes: Ceramic and wooden mortals and pestles, Weighing balances, Digital stop watch, Plastic containers, Sieve $(63 \mu \mathrm{m})$, Crucibles, Beakers, Volumetric flask and Measuring cylinders others are Magnetic stirrer, Digital water bath, Filter paper, Sample bottles, $\mathrm{X}$-Ray fluorescence (XRF) machine, BET analysis machine and Atomic Adsorption Spectrophotometer (AAS).

\section{Sample Collection}

The bentonite clay sample was collected from Adamawa State, North-East of Nigeria.

\section{Sample Preparation}

\section{a. Beneficiation Process}

The raw bentonite clay lumps sample was obtained from Adamawa State, North East Nigeria and sun dried to reduce moisture content and enhance grinding. The surface area of the bentonite sample was reduced to enhance drying of the sample. The clay lumps was crushed down to coarse powder form using wooden mortar and pestle. 10kg of the coarse powder was weighed and soaked in 90 litres of portable water in plastic container and the mixture was allowed to stay overnight (24 hours) to properly dissolve. The mixture was agitated (stirred) for 3 hours at room temperature to separate bonded clay from clay minerals and allow the clay to mix with water. The stirred mixture was allowed to remain in the container overnight (24 hours). The mixture was then plunged for another 3 hours at room temperature for proper separation of bonded clay with quartz and clay minerals. The stirred mixture was allowed to remain in the container for 24 hours for the coarse quartz impurities to sediment to the bottom leaving colloidal solution of bentonite at the top. The solution was sieved through a 23 mesh
Tyler sieve $(63 \mu \mathrm{m}$ sieve opening) and the quartz washed to recover clay, then the clay solution allowed to settle for 120 hours ( 5 days) to allow the bentonite sediment and thicken at the bottom of the container. The thicken bentonite was scrubbed to a filter clothe and pressed under a hydraulic press for 72 hours ( 3 days) to squeeze out the water content. The resulting cake was kneaded into small lumps and air-dried using a trampoline at room temperature. The sample was later Sun-dried and oven dried at $120^{\circ} \mathrm{C}$ to a constant weight, broken down to powder for subsequent experiment. The beneficiation process was allowed for 19 days to complete.

\section{b. Calcination of the Beneficiated Bentonite Clay}

$150 \mathrm{~g}$ of the beneficiated clay was fired gradually in an electric furnace to $700^{\circ} \mathrm{C}$ and soaked at that temperature for 3 hours. The calcined clay was allowed to cool and analyzed.

\section{c. Acidification of the Calcined Bentonite}

$20 \mathrm{~g}$ of the clay calcined was treated with $\mathrm{HCl}$ acid using wet methods. Preparations were made, but this time the bentonite was soaked in $3 \mathrm{M}$ of $\mathrm{HCl}$ acid solution and stirred, filtered and the residue dried. The acidified clay sample was taking for XRF, and BET analysis to determine the chemical composition of the clay and surface area respectively.

\section{E. Preparation of Stock Solution}

A $1.5985 \mathrm{~g}$ of $\mathrm{Pb}\left(\mathrm{NO}_{3}\right)_{2}$ was dissolved in $1000 \mathrm{mls}$ volumetric flask and dilluted with deionized water to the mark. This gave 1000 pmm of Lead stock solution. 10mls of the stock solution was measured using the measuring cylinder and poured into a $1000 \mathrm{mls}$ volumetric flask which is then dilluted to the mark to give a solution of $10 \mathrm{ppm}$ of Lead (II). From the stock solution, 20ppm, 30ppm, 40ppm and 50ppm was prepared the same way as the 10ppm. These was then used for the adsorption experiment.

\section{F. Sorption Experiment}

Batch investigation was conducted by varying the following process parameters; initial metal ion concentration, contact time, temperature and $\mathrm{pH}$ respectively.

\section{a. Effect Initial Metal Ions Concentration}

$50 \mathrm{mls}$ of Lead solution of concentration 10ppm was added to $0.5 \mathrm{~g}$ of bentonite and stirred for 30minutes after which it was filtered and the filtrate stored in the sample bottle for AAS analysis. The process was repeated for metal ion concentration of $20 \mathrm{ppm}, 30 \mathrm{ppm}, 40 \mathrm{ppm}$ and $50 \mathrm{ppm}$ respectively.

\section{b. $\quad$ Effect of Contact Time on Adsorption}

$50 \mathrm{mls}$ of Lead solution of concentration 30ppm was added to $0.5 \mathrm{~g}$ of bentonite and then stirred for 10minutes after which it was filtered and the filtrate stored in the sample bottle for AAS analysis.

The process was repeated for contact time of 20minutes, 30minutes, 40minutes and 50minutes. 


\section{International Journal of Engineering Applied Sciences and Technology, 2019 \\ Vol. 4, Issue 4, ISSN 2455-2143, Pages 394-401 \\ Published Online August 2019 in IJEAST (http://www.ijeast.com)}

c.

Evaluation of the Adsorptive Capacity of Acidified Bentonite Clay

In this study, the adsorption capacity of the acidified-bentonite clay towards the removal of the $\mathrm{Pb}$ (II) ion, the effects of concentration of adsorptive solution, temperature, contact time, and $\mathrm{pH}$ of the solutions were investigated.

The amount of adsorbed metal ion can be calculated using eguation 1 and. 2.

$\%$ Amount adsorbed $=\left(\mathrm{Q}_{\mathrm{i}}-\mathrm{Q}_{\mathrm{f}}\right) / \mathrm{Q}_{\mathrm{i}} \mathrm{X} 100 \quad$. . . (1)

$$
\mathrm{Q}_{\mathrm{e}}=\left(\mathrm{Q}_{\mathrm{i}}-\mathrm{Q}_{\mathrm{f}}\right) \mathrm{V} / \mathrm{m}
$$

where

$\mathrm{Q}_{\mathrm{e}}=$ metal ion uptake (sorption capacity) in $\mathrm{mg} / \mathrm{g}$

$\mathrm{Q}_{\mathrm{i}}=$ initial metal ion concetration in $\mathrm{mg} / \mathrm{l}$

$\mathrm{Q}_{\mathrm{f}}=$ final metal ion concentration in $\mathrm{mg} / \mathrm{l}$

$$
\begin{aligned}
& \mathrm{V}=50 \mathrm{ml} \\
& \mathrm{m}=0.5 \mathrm{~g}
\end{aligned}
$$

\section{d. Effect of Temperature on Adsorption}

$50 \mathrm{mls}$ of Lead solution of concentration $30 \mathrm{ppm}$ was added to $0.5 \mathrm{~g}$ of bentonite and then stirred for 30 minutes at $30^{\circ} \mathrm{C}$ in a digital water bath after which it was filtered and the filtrate stored in the sample bottle for AAS analysis. The process was repeated for temperature of $40^{\circ} \mathrm{C}, 50^{\circ} \mathrm{C}$ and $60^{\circ} \mathrm{C}$ and $70^{\circ} \mathrm{C}$.

\section{e. Effect of pH on Adsorption}

$50 \mathrm{mls}$ of Lead solution of concentration $30 \mathrm{ppm}$ was added to $0.5 \mathrm{~g}$ of bentonite and then stirred for 30minutes at $\mathrm{pH}$ of 4.0 after which it was filtered and the filtrate stored in the sample bottle for AAS analysis. The process was repeated for $\mathrm{pH}$ of 6.0 , 9.0, 11.0, and 12.0.

\section{RESULTS}

Table 3.1: Chemical Composition of Acidified Bentonite Clay using XRF.

\begin{tabular}{|c|c|}
\hline Element & Composition (wt \%) \\
\hline $\mathrm{Al}$ & 15.5 \\
\hline $\mathrm{Si}$ & 50.6 \\
\hline $\mathrm{K}$ & 8.82 \\
\hline $\mathrm{Ca}$ & 1.79 \\
\hline $\mathrm{Ti}$ & 1.89 \\
\hline $\mathrm{V}$ & 0.078 \\
\hline $\mathrm{Cr}$ & 7.08 \\
\hline $\mathrm{Mn}$ & 0.17 \\
\hline $\mathrm{Fe}$ & 13.42 \\
\hline $\mathrm{Cu}$ & 0.029 \\
\hline $\mathrm{Zn}$ & 0.043 \\
\hline $\mathrm{Ga}$ & 0.038 \\
\hline $\mathrm{Au}$ & 0.17 \\
\hline $\mathrm{Eu}$ & 0.26 \\
\hline $\mathrm{Re}$ & 0.1 \\
\hline Total & $\mathbf{9 9 . 9 8 8}$ \\
\hline & \\
\hline & \\
\hline
\end{tabular}

Table 3.2: Bet Analysis

\begin{tabular}{|c|c|}
\hline Parameters & Values \\
\hline Micropore volume $\left(\mathrm{cm}^{3} / \mathrm{g}\right)$ & 1.746 \\
\hline Micropore area $\left(\mathrm{m}^{2} / \mathrm{g}\right)$ & 1424.3 \\
\hline
\end{tabular}

Table 3.3: Effect of initial metal ion concentration on Adsorption

\begin{tabular}{|c|c|c|c|c|}
\hline $\begin{array}{c}\mathbf{Q}_{\mathbf{i}} \\
(\mathbf{p p m})\end{array}$ & $\begin{array}{c}\mathbf{Q}_{\mathbf{f}} \\
(\mathbf{p p m})\end{array}$ & $\begin{array}{c}\text { Amount } \\
\text { adsorbed } \\
(\mathbf{p p m})\end{array}$ & $\begin{array}{c}\% \\
\text { Amount } \\
\text { adsorbed }\end{array}$ & $\mathbf{Q}_{\mathbf{e}}(\mathbf{p p m})$ \\
\hline 10.0 & 1.2995 & 8.7005 & 87.0050 & 870.0500 \\
\hline 20.0 & $\mathrm{ND}$ & - & - & - \\
\hline 30.0 & 0.7685 & 29.2315 & 97.4383 & 2923.1500 \\
\hline 40.0 & $\mathrm{ND}$ & - & - & - \\
\hline 50.0 & 0.4103 & 49.5897 & 99.1794 & 4958.9700 \\
\hline
\end{tabular}

Table 3.4: Effect of Temperature on adsorption

\begin{tabular}{|c|l|c|c|c|}
\hline $\begin{array}{l}\text { Temperature } \\
\text { variation } \\
(\mathbf{m i n})\end{array}$ & $\begin{array}{c}\mathbf{Q}_{\mathbf{f}} \\
(\mathbf{p p m})\end{array}$ & $\begin{array}{c}\text { Amount } \\
\text { adsorbed } \\
(\mathbf{p p m})\end{array}$ & $\begin{array}{c}\text { \% } \\
\text { Amount } \\
\text { adsorbe } \\
\mathbf{d}\end{array}$ & $\begin{array}{c}\mathbf{Q}_{\mathbf{e}} \\
(\mathbf{p p m})\end{array}$ \\
\hline 30.0 & 0.5052 & 29.4948 & 98.3160 & 2949.4800 \\
\hline 40.0 & 0.1634 & 29.8366 & 99.4553 & 2983.6600 \\
\hline 50.0 & 1.1448 & 28.8552 & 96.1840 & 2885.5200 \\
\hline 60.0 & ND & - & - & - \\
\hline 70.0 & 0.0742 & 29.9258 & 99.7527 & 2992.5800 \\
\hline
\end{tabular}

Table 3.5: Effect of Contact Time on Adsorption

\begin{tabular}{|c|c|c|c|c|}
\hline $\begin{array}{c}\text { Time } \\
\text { variation } \\
(\mathbf{m i n})\end{array}$ & $\begin{array}{c}\mathbf{Q}_{\mathbf{f}} \\
(\mathbf{p p m})\end{array}$ & $\begin{array}{c}\text { Amount } \\
\text { adsorbed } \\
(\mathbf{p p m})\end{array}$ & $\begin{array}{c}\mathbf{\%} \\
\text { Amount } \\
\text { adsorbed }\end{array}$ & $\mathbf{Q}_{\mathbf{e}}(\mathbf{p p m})$ \\
\hline 10.0 & 0.0211 & 29.9789 & 99.9297 & 2997.8900 \\
\hline 20.0 & $\mathrm{ND}$ & - & - & - \\
\hline 30.0 & 0.9842 & 29.0158 & 96.7193 & 2901.5800 \\
\hline 40.0 & 1.2623 & 28.7377 & 95.7923 & $2873.77 \mathrm{OO}$ \\
\hline 50.0 & $\mathrm{ND}$ & - & - & - \\
\hline
\end{tabular}


Table 3.6: Effect of pH on Adsorption

\begin{tabular}{|c|c|c|c|c|}
\hline $\begin{array}{c}\mathbf{p H} \\
\text { Variation }\end{array}$ & $\begin{array}{c}\mathbf{Q}_{\mathrm{f}} \\
(\mathbf{p p m})\end{array}$ & $\begin{array}{c}\text { Amount } \\
\text { adsorbed } \\
(\mathbf{p p m})\end{array}$ & $\begin{array}{c}\% \\
\text { Amount } \\
\text { adsorbed }\end{array}$ & $\mathbf{Q}_{\mathrm{e}}$ (ppm) \\
\hline 4.0 & 3.0473 & 26.9527 & 89.84 & 2695.2700 \\
\hline 6.0 & 0.3572 & 29.6428 & 98.81 & 2964.2800 \\
\hline 9.0 & $\mathrm{ND}$ & - & - & - \\
\hline 11.0 & 1.6887 & 28.3113 & 94.37 & 2831.1300 \\
\hline 12.0 & 0.6603 & 29.3397 & 97.80 & 2933.9700 \\
\hline
\end{tabular}

Table 3.7: Langmiur and Freundlich Adsorption isotherms of $\mathrm{Pb}^{2+}$ on Acidified Bentonite Clay.

\begin{tabular}{|c|c|c|c|c|c|c|}
\hline $\mathbf{Q}_{\mathbf{i}}$ & $\begin{array}{c}\mathrm{Q}_{\mathbf{f}} \\
(\mathrm{mg} / \mathrm{L})\end{array}$ & $\begin{array}{c}Q_{\mathrm{e}} \\
(\mathrm{mg} / \mathrm{g})\end{array}$ & $\begin{array}{c}1 / Q_{e} \\
(\mathrm{~g} / \mathrm{mg})\end{array}$ & $\begin{array}{c}1 / Q_{F} \\
(\mathrm{~L} / \mathrm{mg})\end{array}$ & $\begin{array}{c}\mathbf{L o g} \\
Q_{e}\end{array}$ & $\begin{array}{c}\mathbf{L o g} \\
\mathbf{Q}_{\mathbf{F}}\end{array}$ \\
\hline 10.0 & 1.2995 & 17.4010 & 0.0575 & 0.7695 & 1.2406 & 0.1138 \\
\hline 20.0 & - & - & - & & - & - \\
\hline 30.0 & 0.7685 & 58.4630 & 0.0171 & 1.3012 & 1.7669 & $\begin{array}{c}- \\
0.1144\end{array}$ \\
\hline 40.0 & - & - & - & - & - & \\
\hline 50.0 & 0.4103 & 99.1794 & 0.010 & 2.4372 & 1.9964 & $\begin{array}{c}- \\
0.3869\end{array}$ \\
\hline
\end{tabular}

Table 3.8: Adsorption Kinetic Model for $\mathrm{Pb}^{2+}$ Adsorption on Acidified Bentonite Clay.

\begin{tabular}{|c|c|c|c|c|c|c|}
\hline $\begin{array}{c}\mathbf{t} \\
(\mathbf{m i n})\end{array}$ & $\begin{array}{c}\mathbf{Q}_{\mathbf{f}} \\
(\mathbf{m g} / \mathbf{g})\end{array}$ & $\begin{array}{c}\mathbf{Q}_{\mathbf{t}} \\
(\mathbf{m g} / \mathbf{g})\end{array}$ & $\mathbf{Q}_{\mathrm{e}^{-}} \mathbf{Q}_{\mathbf{t}}$ & $\begin{array}{c}\mathbf{L o g} \\
\left(\mathbf{Q}_{\mathrm{e}^{-}}\right. \\
\left.\mathbf{Q}_{\mathbf{t}}\right)\end{array}$ & $\begin{array}{c}\mathbf{t} / \mathbf{Q}_{\mathbf{t}} \\
\mathbf{m i n} \\
(\mathbf{m g} / \mathbf{g})\end{array}$ & $\begin{array}{c}\mathbf{t}^{\mathbf{1} / 2} \\
(\mathbf{m i} \\
\mathbf{n})^{\mathbf{1 / 2}}\end{array}$ \\
\hline 10 & 0.0211 & $\begin{array}{c}29.978 \\
9\end{array}$ & $\begin{array}{c}0.000 \\
0\end{array}$ & 0.0000 & 0.3336 & $\begin{array}{c}3.16 \\
23\end{array}$ \\
\hline 20 & - & - & - & - & - & - \\
\hline 30 & 0.9842 & 29.015 & 0.963 & - & 1.0339 & 5.47 \\
& & 8 & 1 & 0.0177 & & 72 \\
\hline 40 & 1.2623 & 28.737 & 1.241 & 0.0934 & 1.3919 & 6.32 \\
& & 7 & 2 & & & 46 \\
\hline 50 & - & - & - & - & - & - \\
\hline
\end{tabular}

Table 3. 9: Thermoodynamic of Adsorption of $\mathrm{Pb}^{2+}$ on Acidified Bentonite Clay

\begin{tabular}{|c|c|c|c|c|c|c|c|}
\hline $\begin{array}{c}\mathbf{T} \\
{ }^{\mathbf{K}}\end{array}$ & $\begin{array}{c}\mathbf{1} / \mathbf{T} \\
{ }^{\mathbf{0}} \mathbf{K}^{-\mathbf{1}}\end{array}$ & $\mathbf{Q}_{\mathbf{f}}$ & $\mathbf{Q}_{\mathbf{e}}$ & $\mathbf{K}_{\mathbf{C}}$ & $\begin{array}{c}\mathbf{L o g} \\
\mathbf{K}_{\mathbf{C}}\end{array}$ & $\boldsymbol{\Theta}$ & $\begin{array}{c}(\mathbf{1 -} \\
\mathbf{\Theta})\end{array}$ \\
\hline 303 & 0.0033 & 0.5052 & 29.4948 & 57.8242 & 1.7621 & 0.9794 & 0.0201 \\
\hline 313 & 0.0032 & 0.1634 & 29.8366 & 182.5985 & 2.2615 & 5.1199 & - \\
\hline 323 & 0.0031 & 1.1448 & 28.8552 & 25.2055 & 1.4015 & -0.1265 & 1.1265 \\
\hline 333 & 0.0030 & - & - & - & - & - & - \\
\hline 343 & 0.0029 & 0.0742 & 29.9258 & 403.3127 & 2.6056 & 12.4771 & - \\
& & & & & & & $\begin{array}{c}1.477 \\
1\end{array}$ \\
\hline
\end{tabular}

Table 3.10: Adsorption Isotherm Constants for $\mathbf{P b}^{2+}$ Sorption on Acidified Bentonite Clay

\begin{tabular}{|c|c|}
\hline Langmuir Isotherm & Freundlich Isotherm \\
\hline $\mathrm{Q}_{\max }=15.3846$ & $1 / \mathrm{n}=1.4880$ \\
\hline $\mathrm{K}_{\mathrm{L}}=-2.6001$ & $\mathrm{~K}_{\mathrm{f}}=29.8538$ \\
\hline- & $\mathrm{n}=0.6720$ \\
\hline $\mathrm{R}^{2}=0.689$ & $\mathrm{R}^{2}=0.5669$ \\
\hline
\end{tabular}

Table 3.11: Dimensionless Langmuir Separation Factor

\begin{tabular}{|c|c|c|c|c|c|}
\hline Conc & 10 & 20 & 30 & 40 & 50 \\
\hline $\mathbf{m g} / \mathbf{L})$ & & & & & \\
\hline $\mathbf{R}_{\mathbf{L}}$ & -0.04 & -0.0196 & -0.01299 & -0.0001 & -0.0078 \\
& & & & & \\
\hline
\end{tabular}

Table 3.12: Kinetic Parameters for Adsorption of $\mathbf{P b}^{2+}$ onto Acidified Bentonite Clay.

\begin{tabular}{|c|c|c|}
\hline $\begin{array}{c}\text { Pseudo-first } \\
\text { order }\end{array}$ & $\begin{array}{c}\text { Pseudo-second } \\
\text { order }\end{array}$ & $\begin{array}{c}\text { Intra-particle } \\
\text { diffusion }\end{array}$ \\
\hline $\mathrm{K}_{\mathrm{ad}}=-0.0046$ & $\mathrm{~K}_{2}=-0.064$ & $\mathrm{~K}_{\mathrm{d}}=-0.397$ \\
\hline $\mathrm{Q}_{\mathrm{e}}, \mathrm{Cal}=-$ & $\mathrm{Q}_{\mathrm{e}}, \mathrm{Cal}=$ & $\mathrm{I}=31.22$ \\
0.0046 & 28.5714 & \\
\hline $\mathrm{R}^{2}=0.423$ & $\mathrm{R}^{2}=1$ & $\mathrm{R}^{2}=0.997$ \\
\hline
\end{tabular}

Table 3.13: Thermodynamic Parameters for Adsorption of $\mathrm{Pb}^{2+}$ onto Acidified Bentonite Clay

\begin{tabular}{|c|c|}
\hline $\begin{array}{c}\text { Temperature } \\
\mathbf{T}\left({ }^{\mathbf{0}} \mathbf{K}\right)\end{array}$ & $\begin{array}{c}\text { Gibbs Free } \\
\left.\text { Energy } \Delta \mathbf{G}^{\mathbf{0}} \mathbf{K J} \mathbf{K} / \mathbf{m o l}\right)\end{array}$ \\
\hline 303 & -10221.0023 \\
\hline 313 & -13593.2431 \\
\hline 323 & -8666.0239 \\
\hline 333 & - \\
\hline 343 & 17109.3913 \\
\hline
\end{tabular}




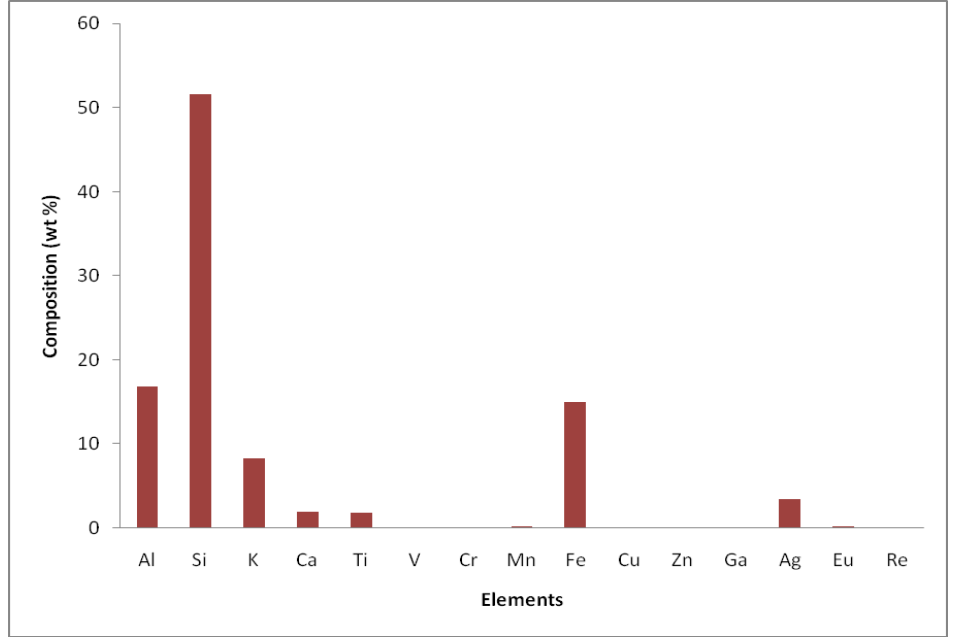

Figure 1: Elemental composition of Acidified Bentonite Clay.

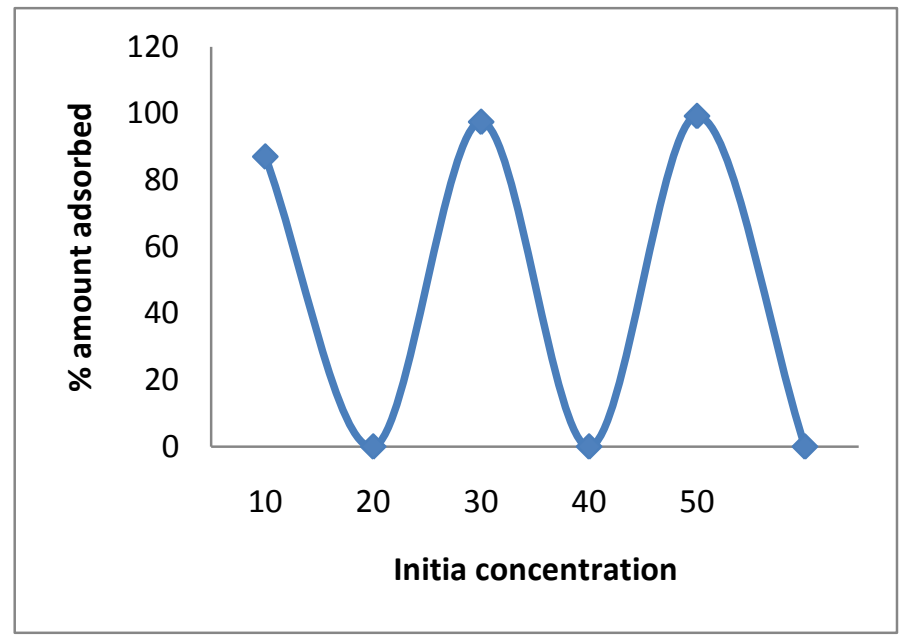

Figure 2: Effect of initial ion concentration on amount adsorbed

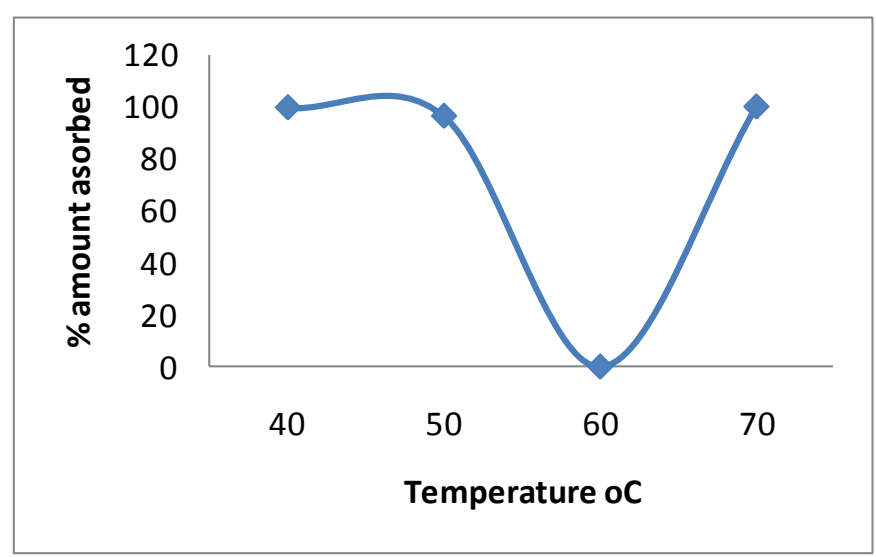

Figure 3: Effect of temperature on amount adsorbed

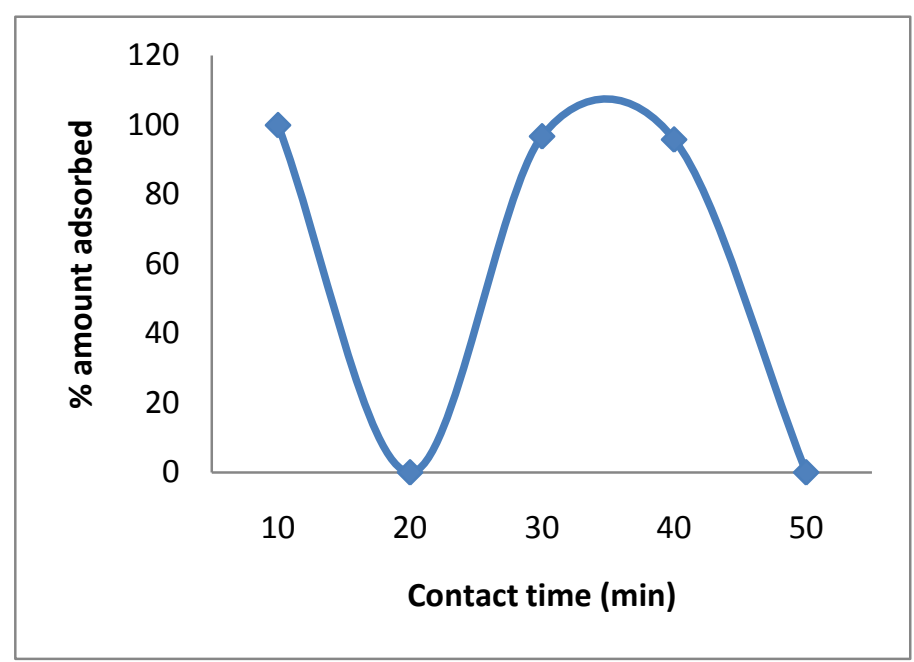

Figure 4: Effect of contact time on amount adsorbed

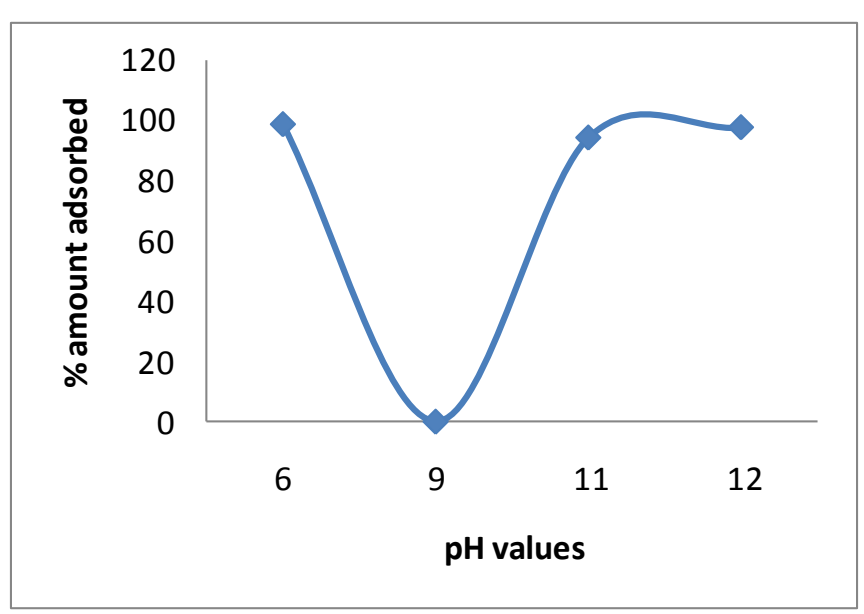

Figure 5: Effect pH on amount adsorbed

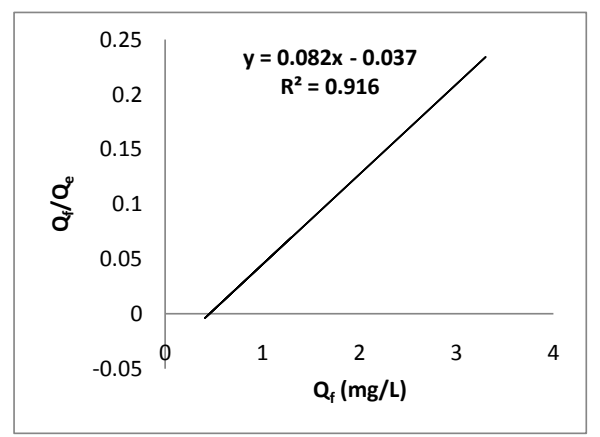

Figure 6: Langmuir Isotherm for Adsorption of $\mathrm{Pb}(\mathrm{II})$ on Acidified Bentonite Clay 


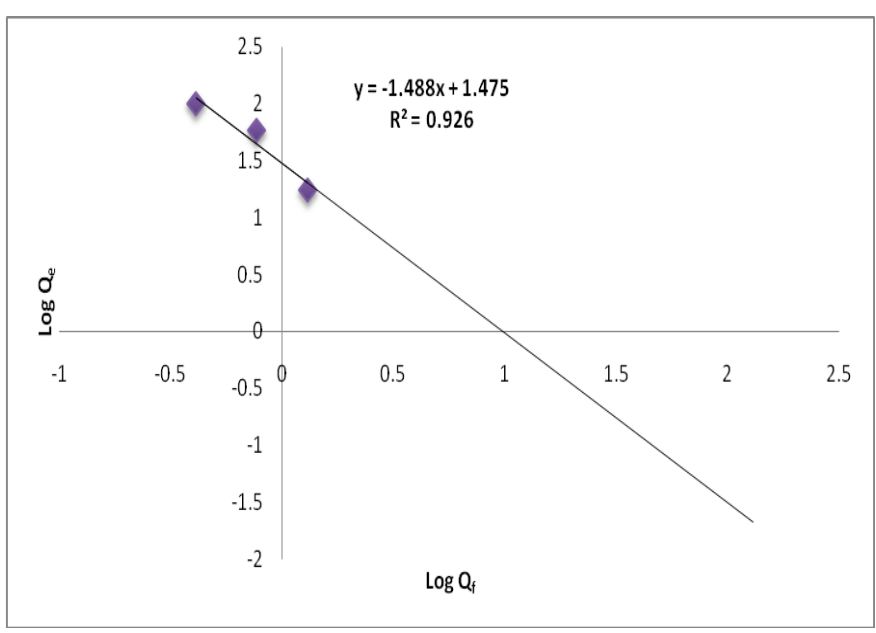

Figure 7: Freundlich Isotherm for the Adsorption of $\mathrm{Pb}$ (II) ion on Acidified Bentonite Clay

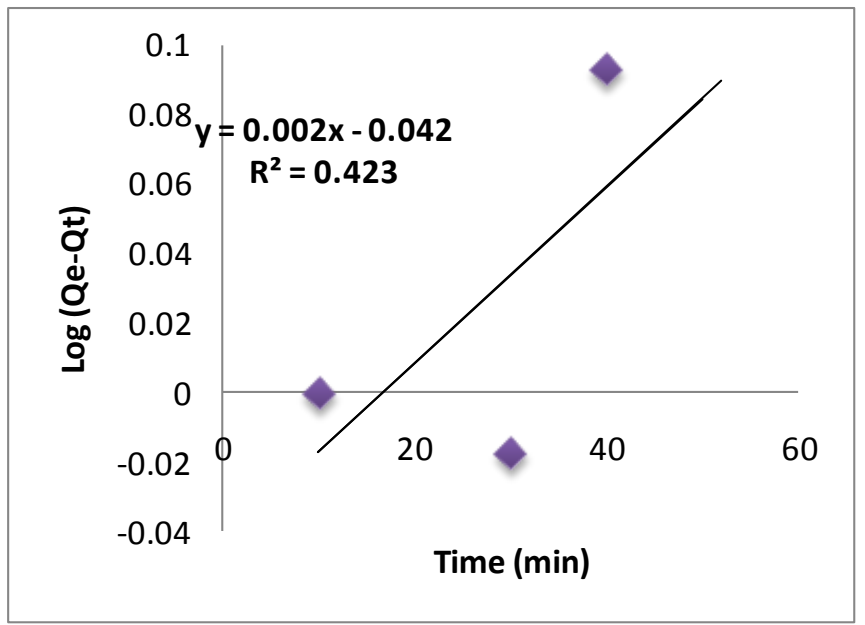

Figure 8: First Order Kinetic for Adsorption of $\mathrm{Pb}(\mathrm{II})$ Ion on Acidified Bentonite Clay

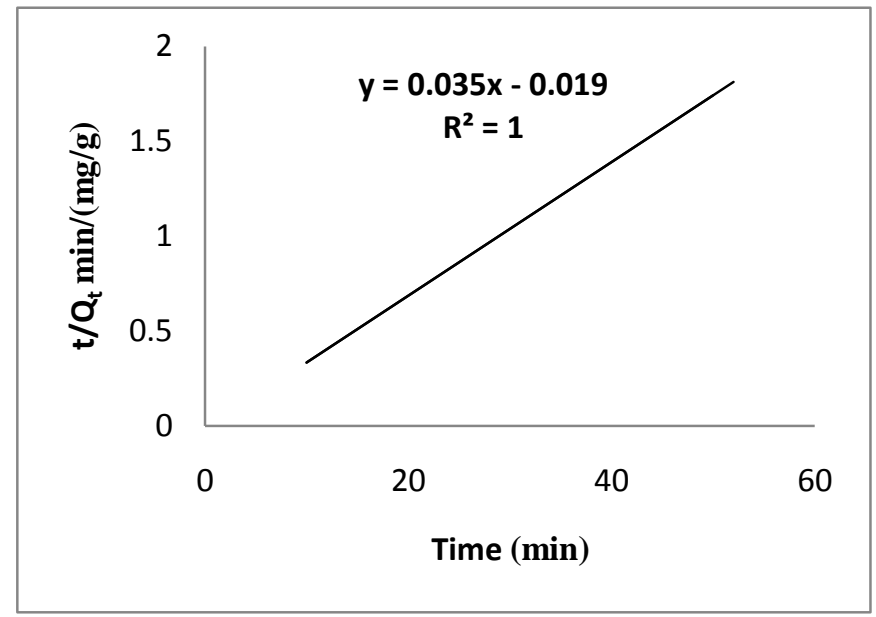

Figure 9: Second Order Kinetic for Adsorption of $\mathrm{Pb}$ (II) Ion by Acidified Bentonite Clay

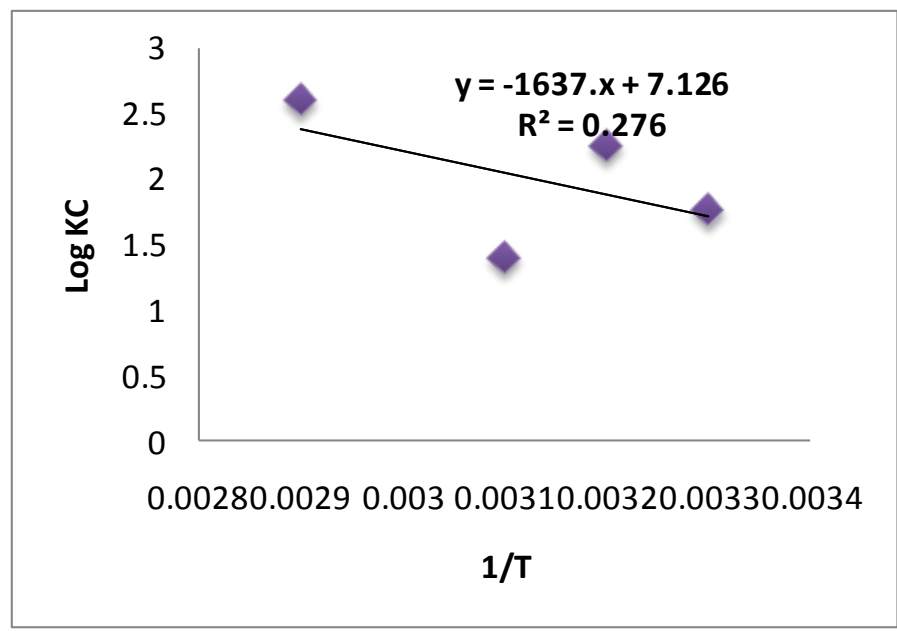

Figure 10: $\operatorname{LogK}_{\mathrm{c}}$ versus 1/T for Adsorption of $\mathrm{Pb}(\mathrm{II})$ ion onto Acidified Bentonite Clay

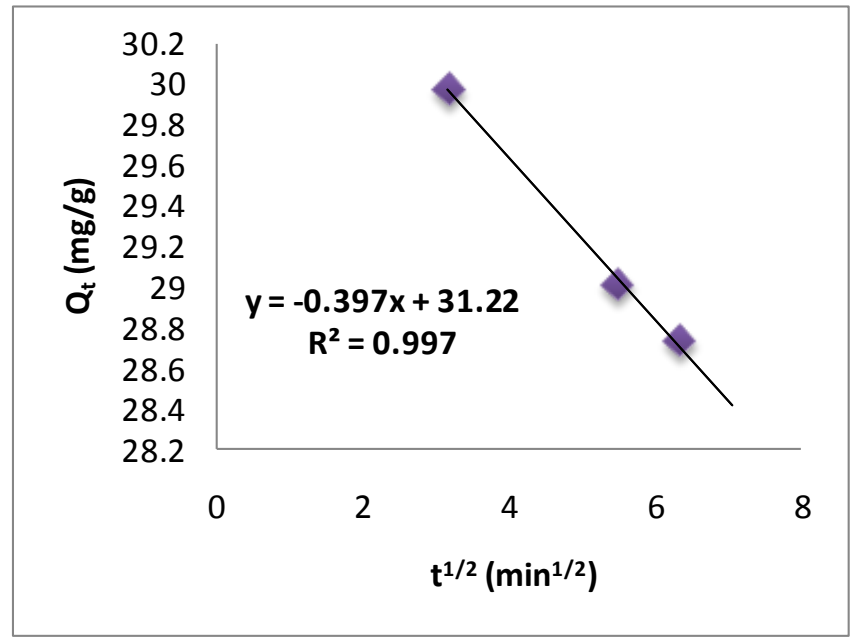

Figure 11: Intra-Particle Diffusion for Adsorption of Lead ion onto Acidified Bentonite Clay

\section{DISCUSSION}

\section{A. CHEMICAL ANALYSIS OF ACIDIFIED BENTONITE CLAY}

Chemical analysis was carried out on acidified bentonite clay using X-Ray Fluorescence Spectrometer (XRF) to determine the chemical composition of the clay. The result of chemical analysis of acidified bentonite sample shows that, it is composed of $\mathrm{Al}(15.50 \%), \mathrm{Si}(50.60 \%), \mathrm{K}(8.82 \%), \mathrm{Ca}(1.79 \%), \mathrm{Ti}$ (1.89\%), V (0.08\%), Cr (7.08\%), Mn (0.17\%), Fe (13.42\%), Cu (0.03\%), Zn (0.04\%), Ga (0.04\%), Au (0.17\%), Eu (0.26\%), and $\operatorname{Re}(0.10 \%)$, as shown in Table 1 and Figure 1 . The composition of the clay composed of $\mathrm{Si}$, and $\mathrm{Al}$ as major elements, $\mathrm{Fe}, \mathrm{K}, \mathrm{Cr}$, $\mathrm{Ti}$, and $\mathrm{Ag}$ in moderate amount, $\mathrm{V}, \mathrm{Cr}, \mathrm{Mn}, \mathrm{Cu}, \mathrm{Zn}, \mathrm{Ga}, \mathrm{Eu}$, and $\mathrm{Re}$ in trace quantity. This result is in agreement with the literature value which ascertained that clay is majorly composed of silicate and alumina and other elements like $\mathrm{Fe}, \mathrm{Ca}, \mathrm{K}, \mathrm{Cr}$, $\mathrm{Mn}, \mathrm{Cu}, \mathrm{Zn}, \mathrm{Ga}, \mathrm{Au}, \mathrm{Eu}$, and $\mathrm{Re}$ as impurities. 


\section{International Journal of Engineering Applied Sciences and Technology, 2019 Vol. 4, Issue 4, ISSN 2455-2143, Pages 394-401 Published Online August 2019 in IJEAST (http://www.ijeast.com)}

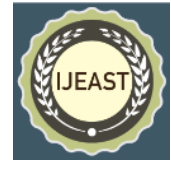

\section{B. BET Analysis}

BET analysis was carried out on acidified- bentonite clay to determine the surface area since the rate of adsorption depends on the surface area of the adsorbent. The result of the analysis is shown in Table 2. The result shows that the micro pore volume is $1.746\left(\mathrm{~cm}^{3}\right)$, and micro pore area is $1424.3\left(\mathrm{~m}^{2} / \mathrm{g}\right)$. Generally clay is associated with a small fraction of the pore volume and is similar to the result obtained from this investigation. The use of a modified BET equation permits a more realistic estimate of the monolayer capacity than that one obtained using the $n=\infty$. The value of micro-pore volume and micro-pore area shows that the clay could lead to better sorption capacity.

\section{Effects of initial metal ion concentration}

The effect of metal ion concentration in the adsorption of lead ions by acidified bentonite clay is illustrated in Table 3.3 and Figure 2. It can be ascertained that the adsorption capacity of acidified bentonite clay for lead ion increased with increasing initial metal ion concentration from $10 \mathrm{ppm}$ to $50 \mathrm{ppm}$. At the concentration of $10.0 \mathrm{ppm}, 87.01 \%$ of lead ion was adsorbed and no amount of lead ion was detected at $20 \mathrm{ppm}$. This could be due to unavailability of active site of the adsorbent. At the initial concentration of 30ppm, $97.44 \%$ adsorption was recorded and no amount was observed at $40 \mathrm{ppm}$. Maximum adsorption of $99.18 \%$ was recorded at initial concentration of $50 \mathrm{ppm}$ as shown in Figure 2. This regular increase in efficiency of the bentonitic clay could be due to the availability of the unoccupied surface area of the bentonite since adsorption depends on the surface area of the adsorbent (Qadeer and Akhtar, 2005).

\section{Effect of Temperature on Adsorption.}

The effect of temperature on the removal of $\mathrm{Pb}^{2+}$ is shown in Table 3. 4. The result shows that the adsorption capacity of acidified-bentonite clay increase with increasing temperature from $30^{\circ} \mathrm{C}$ to $40^{\circ} \mathrm{C}$ and later decreases from $40^{\circ} \mathrm{C}$ to $50^{\circ} \mathrm{C}$ and again increased at $70^{\circ} \mathrm{C}, 98.32 \%$ of $\mathrm{Pb}^{2+}$ was adsorbed at the temperature of $30^{\circ} \mathrm{C}$. At $40^{\circ} \mathrm{C}, 50^{\circ} \mathrm{C}$ the amount adsorbed were $99.46 \%, 96.18 \%$ of respectively and no amount of percentage adsorption was detected at the temperature of $60^{\circ} \mathrm{C}$, this could be due to complete occupied active sites. At $70^{\circ} \mathrm{C}$, the amount adsorbed was $99.75 \%$ which indicate the maximum adsorption. From the result in Figure 3 and Table 3.4, it shows that the rate of adsorption depends on the temperature, though the fluctuation in the percentage adsorbed may be due to experimental error.

\section{E. Effect of Contact Time on Adsorption}

The rate of adsorption is an important parameter in the treatment of industrial wastewater. The time-dependent behavior of $\mathrm{Pb}^{2+}$ was measured by varying the equilibrium time between the adsorbate and adsorbent in the range of 10-50 min, constant initial concentration of $30 \mathrm{ppm}$ and $0.5 \mathrm{~g}$ were maintained throughout the experiment. The effect of contact time on the removal of $\mathrm{Pb}^{2+}$ is presented in Table 3.5, and Figure 4. It can be seen that the rate of adsorption of $\mathrm{Pb}^{2+}$ decreases with increasing contact time. At the contact time of $10 \mathrm{~min}, 99.93 \%$ was adsorbed which shows that maximum adsorption was reached very quickly, indicating that the adsorption sites were well exposed for adsorption to take place. The percentage amount adsorbed was not detected at $20 \mathrm{~min}$. this may be due to insufficient active sites for more adsorption to take place or due to experimental error. At 30min, 40min, the amount adsorbed were $96.72 \%$ and $95.79 \%$ respectively and no amount of adsorption was detected at $50 \mathrm{~min}$. This result shows that maximum adsorption was reach very quickly at the initial contact time, further increase in contact time lead to decrease in adsorption. This could be as a result of the force of repulsion between the adsorbate and adsorbent molecules on the bentonite surface in the bulk phase.

\section{F. Effect of pH on the Adsorption}

The $\mathrm{pH}$ of the aqueous solution is an important variable governing metal adsorption. Hence, it is obvious that this is partly due to the fact that the competition between hydrogen ions and the solution of $\mathrm{pH}$ affect the chemical composition as well as the ionization of the functional groups onto the adsorbent surface (Kadirvely and Namasivayam, 2003). The effect of $\mathrm{pH}$ on the adsorption of $\mathrm{Pb}^{2+}$ onto the bentonite was investigated as shown in Table 3.6, and Figure 5. The uptake of $\mathrm{Pb}^{2+}$ increases with increasing $\mathrm{pH}$ from 4.0 to 6.0 . The increase in metal removal as $\mathrm{pH}$ increases can be explained on the basis of decrease in competition between the hydronium ions and the lead species for the surface sites and also by decrease in positive surface charge on the adsorbent which lower the electrostatic force of repulsion between the surface of the bentonite and the metal ion. Hence, adsorption of $\mathrm{Pb}^{2+}$ increases (Pat nukao et al, 2008). At the $\mathrm{pH}$ of $4.0,6.0$ the amount adsorbed were $89.84 \%$ and $98.81 \%$ respectively and no amount of $\mathrm{Pb}^{2+}$ was adsorbed at $\mathrm{pH}$ of 9.0 which could be due to insufficient or unavailability of active site. At the $\mathrm{pH}$ of $11.0,94.37 \%$ of lead was adsorbed and finally $97.10 \%$ was adsorbed at the $\mathrm{pH}$ of 12.0 this variation in the rate of adsorption is in agreement with the result of Ulmanu et al (2003).

\section{B. Adsorption Isotherm Modeling}

The linear form of Langmuir and Freundlich isotherm for the adsorption of $\mathrm{Pb}^{2+}$ onto acidified bentonite clay is shown in Figure 6 and Figure 7. The Langmuir and the Freundlich constants were determined using correlation coefficient (Table 3.7). A moderate regression correlation coefficient $<1.0$ were found in the studied isotherms. According to these results, the Langmuir and the Freundlich models are suitable for the description of adsorption of $\mathrm{Pb}^{2+}$ by acidified bentonite at equilibrium in the studied concentration range. The sorption isotherm is characterized by certain constants, in which the values are expressed as the surface properties and affinity of the adsorbent can also be used to find the adsorption capacity of the clay. The magnitude of $\mathrm{K}_{\mathrm{f}}$ and $1 / \mathrm{n}$ values was found as 29.85 and 1.488 respectively. It also indicates that the value of $1 / \mathrm{n}$ is less than 1 which shows that adsorption of $\mathrm{Pb}^{2+}$ by the bentonite clay is a favorable adsorption mechanism and form a relatively strong bond between the adsorbate and the adsorbent (Egila et al., 2010). The value of $\mathrm{Q}_{\max }$ and $\mathrm{K}_{\mathrm{L}}$ were also obtained from Langmuir plot in Figure 6 and the result shown in Table 3.7. The maximum adsorption capacity $\mathrm{Q}_{\max }$ determined from the Langmuir isotherm defined the total capacity of the adsorbent (15.3846 mg/g). The negative value of $\mathrm{K}_{\mathrm{L}}(-2.60)$ implies a weak positive bonding relationship of $\mathrm{Pb}^{2+}$ to the clay. The separation factor values for all initial concentration Table 3.11. Were found to be less than 1 , indicates a favorable sorption of $\mathrm{Pb}^{2+}$ onto the clay (Asiagwu, 2012).

C. Thermodynamic Treatment of the Sorption Process The thermodynamic treatment of the sorption data shows that change Gibbs free energy $\Delta G^{\circ}$ values were negative at all 


\section{International Journal of Engineering Applied Sciences and Technology, 2019 \\ Vol. 4, Issue 4, ISSN 2455-2143, Pages 394-401 \\ Published Online August 2019 in IJEAST (http://www.ijeast.com)}

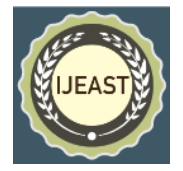

temperature (Table 3.13). The negative values indicate the spontaneous nature of adsorption of metal ions by acid bentonite clay.

\section{CONCLUSION}

The investigation shows that acidified bentonite clay is an effective adsorbent for the removal of $\mathrm{Pb}^{2+}$ from aqueous solutions. The result of lead ions adsorption by the bentonitic clay indicates that it is a good alternative adsorbent for the removal of lead from aqueous solution. Parameters such as initial ion concentration, $\mathrm{pH}$, contact time and temperature on the adsorption of metal ion by the clay in batch experiment were examined and proven to be important parameters in describing adsorption capacity that characterized bentonite clay. Experimental results are in good agreement with Langmuir, and Freundlich isotherm models, and have shown a good fitting to the experimental data. The parameters obtained shows that acidified bentonite clay could be a cheap adsorbent substitute for adsorption and has a high tendency to be used as effective and economical adsorbent for heavy metal removal. Adsorption of $\mathrm{Pb}^{2+}$ obeys pseudo-second order equation with good correlation.

\section{REFERENCES}

1. Asli B, Nil O, Suleyman A. (2013).“ Determination of trace metals in waste water and their removal processes". INTECH, Open Science http//dx.doi.org/10.5772/52025, Waste Water Treatment Technologies and Recent Analytical Developments, (Pp. 145 - 171).

2. Asiagwu, A.K. (2012). Sorption kinetics of $\mathrm{Pb}(\mathrm{II})$ and $\mathrm{Cd}(\mathrm{II})$ ions via biomass surface of plantain peel waste. International Journal of Research and Reviews in Applied Sciences, 13(2): (Pp.626 - 635).

3. Barkat M, Chegrouche S, Mellah A, Bensmain B, Nibou D, Boufatit M. (2014). "Application of Algerian Bentonite in the Removal of Cadmium (II) and Chromium (VI) from Aqueous Solutions". Journal of Surface Engineered Materials and Advanced Technology, Vol.4, (Pp.210-226).

4. Bosch, A. C., Bernadette O’ Neill, Gunnar O. Sigge, Sven E. Kerwath, and Louwrens C. Hoffman. (2016). "Heavy metal accumulation and toxicity in smoothhound (Mustelus mustelus) shark from Langebaan Lagoon, South Africa." Food chemistry 190: (Pp. 871-878).

5. Egila J. N, Dauda B. E. N, Jimoh T. (2010). Biosorptive removal of cobalt (II)ions from aqueous solution by Amaranthus hydridus L. stalk wastes.Afr. J. Biotechnol., 9(48): (Pp. 8192-8198).

6. Grassi M, Kaykioglu G, Belgiorno V, Lofrano G. (2012). "Removal of Emerging Contaminants from Water and Wastewater by Adsorption Process", in" Emerging Compounds Removal from Wastewater: natural and solar based treatments", Editor,G.Lofrano,Springer,NewYork

7. Gutierrez M., FuentsH. (1996).“ A mechanistic modeling of montmorillonite contamination by cesium sorption. Applied Clay Science, 11, (Pp.11-24).

8. Hosterman, J.W. and S.H. Patterson. (1992). Bentonite and Fuller's earth resources of the
United States. U.S. Geological Survey Professional Paper 1522. United States Government Printing Office, Washington D.C., USA.

9. Kadirvelu K., Kavipriya M., Karthika C., Radhika M., Vennilamani N., PattabhiS. (2003).“ Utilization of various agricultural wastes for activated carbon preparation and application for the removal of dye sand metal ions from aqueous solutions". Bioresource Technology, 87(1), (Pp.129- 132).

10. Langmuir, I. (1918). The adsorption of gases on plane surfaces of glass, mica and platinum. J. Am. Chem. Soc., 40, (Pp. 1361-1403).

11. Lenntech, B. V. (2012). Heavy Metals, Available at Website: chart.htm. www.lenntech.co./periodic.periodic-

12. Ming Qin J., Qing Ping W., Xiao Ying J., Liang Zu C. (2009). " Removal of $\mathrm{Pb}(\mathrm{II})$ from aqueous solution using modified and unmodified kaolinite clay" . Journal of Hazardous Materials, 170, (Pp. 332 - 339).

13. Namasivayam. C and Kavitha. D. (2002). "Removal of congored from water $\mathrm{b}$ adsorption onto activated carbonprepared from coir pith, an agricultural solid waste. Dyes and Pigments". 54: (Pp.47-58).

14. Qadeer, R. and Akhtar, S. (2005). "Study of Lead Ion Adsorption of Active Carbon". Turkish Journal of Chemistry, 29, (Pp. 95-99).

15. Ulmanu, M.; Maranon, E.; Fernandez, Y.; Castrillon, L.; Anger,L.; Dumitriu, D., (2003). Removal of copper and cadmiumions from diluted aqueous solutions by low cost and wastematerial adsorbents. Water, Air, Soil Pollut., 142 (1-4), (Pp. 357-373).

16. Pat nukao P, Kongsuwan. A, Pavasant. P. (2008). Journal of Environmental Sciences. 20 (9) 1028-1034.

17. Sher Ali Khan, Zahoor Ud Din, Ihsanullah and Ahmad Zubair. (2011). I.J.S.N. Vol.2(3):648-652 ISSN (Pp.2229-6441)

18. WHO (2011). Guidelines for drinking water quality. World Health Organization, Geneva. 